Kansas State University Libraries

New Prairie Press

\title{
An Examination of the Levels and Differences in Organizational Commitment of Full and Part Time Community College Faculty
}

Duane Akroyd

Deborah Engle

Follow this and additional works at: https://newprairiepress.org/aerc

Part of the Adult and Continuing Education Administration Commons

(c) (i) (9)

This work is licensed under a Creative Commons Attribution-Noncommercial 4.0 License

\section{Recommended Citation}

Akroyd, Duane and Engle, Deborah (2014). "An Examination of the Levels and Differences in Organizational Commitment of Full and Part Time Community College Faculty," Adult Education Research Conference. https://newprairiepress.org/aerc/2014/papers/3

This is brought to you for free and open access by the Conferences at New Prairie Press. It has been accepted for inclusion in Adult Education Research Conference by an authorized administrator of New Prairie Press. For more information, please contact cads@k-state.edu. 


\title{
An Examination of the Levels and Differences in Organizational Commitment of Full and Part Time Community College Faculty
}

\author{
Duane Akroyd, PhD, North Carolina State University \\ Deborah Engle, EdD, Duke University, Duke University School of Medicine
}

Keywords: Faculty, Community College, Organizational Commitment, Part Time Faculty

\begin{abstract}
Despite the widespread employment of part-time faculty in community colleges, there is little known about the commitment levels of these faculty, or how it compares to their full-time counterparts. The purpose of this study was to determine if the levels of affective, continuance, and normative commitment for full-time faculty differed significantly from part-time faculty in North Carolina community colleges? Analysis of variance (ANOVA), found that mean scores of affective, and normative commitment were significantly higher for full-time faculty than part-time faculty.
\end{abstract}

The nascent dependence on part-time employees in organizations represents a relatively recent trend across the modern landscape of the American workforce. As a result, the relationship between organizations and employees is shifting. Over the past 50 years, there have been a multitude of definitions of organizational commitment to arise from the literature. This variety is derived from the various scholarly conceptualizations of organizational commitment (Mowday, Porter, \& Steers, 1982). According to Meyer and Allen (1997), "common to all conceptualizations of commitment is the notion that commitment binds an individual to an organization" (p. 13).

Community college faculty organizational dependence on part-time employees is especially apparent in higher education. Across the United States, the number of part-time faculty members has increased by 79\% between 1981 and 1999 (Walsh, 2002). In North Carolina community colleges, the total number of part-time faculty swelled from 9,093 in the year 2000 to 14,375 in 2006, representing greater than a 50\% increase in just six years (North Carolina Community College System, 2006). Wallin (2004) suggests these dramatic increases in the employment of part-time faculty are significantly due to the economic recession during this period and concurrent large enrollment of students in college. Wallin (2004) cites Rifkin's (2000) work when she states: "because [part-timers] are usually employed elsewhere, they may not have the commitment to the college that is more typical of full-time faculty" (p. 380).

\section{Problem}

Provasnik and Planty (2008) report for the National Center for Education Statistics that over two-thirds of community college faculty across the United States were employed part-time (over 240,000 faculty), while one-third of community college faculty were employed full-time. These national statistics mirror the faculty employment data for North Carolina. In North Carolina, $70 \%$ of the state's community college faculty are part-time, while $30 \%$ are full-time employees (North Carolina Community College System, 2006).

Cohen and Brawer (2003) contend that the explanation for this substantial reliance on part-time faculty is that they cost less; they may have special capabilities not available among the full-time instructors; and they can be employed, dismissed, and reemployed as necessary (p. 85). Frequently, part-time faculty are teaching the same courses and content as their full-time counterparts, while enduring financial inequities in salary, benefits, and professional development (Wallin, 2005). As community colleges' dependence on part-time faculty 
continues, it becomes apparent that these employees are critical to the success of these institutions (Wallin, 2005). Despite this criticality, part-time faculty are "treated as disposable commodities, an expendable contingent work force" (Wallin, 2005, p. 13), are viewed as "indentured servitude" (Yoshioka, 2007, p. 41), and metaphorically linked to "migrant workers to the farms" (Cohen and Brawer, 2003, p. 86). In light of these circumstances, the debate continues whether community colleges and faculty are, or should be, mutually committed. Analyzing levels of organizational commitment and understanding how it is developed for individual employees is therefore a timely and important endeavor for this group.

Over the past 25 years, researchers have observed limitations of this early model of organizational commitment and have argued that it did not fully explain how an individual becomes committed to an organization (Mayer \& Schoorman, 1998). Most notably, Meyer and Allen (1990) re-conceptualized organizational commitment as a multi-dimensional construct consisting of three components: affective, continuance, and normative commitment. Affective commitment is an employee's emotional attachment to his/her organization - the employee remains working at the organization because he/she wants to. Continuance commitment is exhibited when an employee stays at an organization, not because he/she wants to remain there, but because she/he is aware of the costs associated with leaving. Normative commitment is when an employee remains at an organization out of a sense of obligation to stay there. Meyer and Allen's (1991) newer conceptualization of organizational commitment as a three-component model has become a widely-accepted theoretical framework in commitment research (Meyer, Becker, Vandenberghe, 2004).

There seem to be two divergent perspectives about commitment among part-time faculty that exist in the literature. One perspective is that part-time faculty are not as committed to their organizations as their full-time counterparts; the other is that they are just as committed as the full-timers. Clearly, more research is needed to clarify the level of organizational commitment and the factors that influence it for both part-time and full-time faculty employees at community colleges.

\section{Theoretical Framework}

The theory that is framing this study derives from Meyer and Allen's (1997) research on commitment. They propose that individuals become committed for any of three psychological reasons labeled as affective, continuance, and normative. Affective commitment is viewed as an individual's "emotional attachment to, identification with, and involvement with the organization" (Meyer \& Allen, 1997, p. 11). For continuance commitment, an employee chooses to stay with an organization due to an awareness of the costs associated with leaving it. In normative commitment, an individual continues employment due to a sense of obligation. Each of these three components of organizational commitment may be experienced simultaneously and at different levels by all individuals in an organization (Meyer \& Allen, 1997). Over the past 25 years, researchers have observed limitations of early models and measures of organizational commitment and have argued they it did not fully explain an individual's commitment to an organization (Mayer \& Schoorman, 1998). Most notably, Meyer and Allen (1990) reconceptualized organizational commitment as a multi-dimensional construct consisting of three components: affective, continuance, and normative commitment and it has become a widelyaccepted theoretical framework in commitment research (Meyer, Becker, Vandenberghe, 2004).

\section{Purpose}

The purpose of this study was to examine how North Carolina community college fulltime faculty compare to part-time faculty in their level of organizational commitment, more 
specifically we wanted to determine if the levels of affective, continuance, and normative commitment for full-time faculty differed significantly from full part- time faculty in North Carolina community colleges?

\section{Research Design}

The purpose of this study was to examine how North Carolina community college fulltime faculty compare to part-time faculty in their level of organizational commitment. This study was a cross-sectional examination of faculty in their work setting and employed an explanatory non-experimental research design (Johnson, 2001). It utilized quantitative survey methods with appropriate sampling procedures in order to make inferences about all full-time and part-time community college faculty in North Carolina by using a smaller, representative sample of this entire population.

\section{Sample}

The sample was drawn from the 58 community colleges across North Carolina that employ approximately 6,244 full-time faculty (North Carolina Community College System, 2007) and 14,375 part-time faculty (North Carolina Community College System, 2006). During the 13month data collection period, 26 colleges accepted the invitation to participate. Upon conclusion of the data collection period (web based survey gathered from colleges list of faculty email addresses), full-time faculty submitted 645 surveys and part- time faculty submitted 168 surveys.

\section{Organizational Commitment}

\section{Instrumentation}

To measure affective, continuance and normative commitment the scale developed by Meyer and Allen (1993) was used to measure this multi-dimensional construct. It consisted of a 6 Likert-type questions for each of the three types of commitment mentioned above (scale: $1=$ Strongly disagree through $7=$ Strongly agree). The mean of all six questions for each type of commitment (affective, continuance and normative) was used as the measure of employee commitment in the organization.

validity and reliability. Confirmatory factor analyses (Dunham, Grube and Castenada, 1994; Hackett, Bycio and Hausdorf, 1994) have established that each of the commitment scales (ACS, CCS, and NCS) measures distinct components of commitment (Meyer et al., 2002). More recently, Gormley (2005) conducted a principal components analysis for Meyer and Allen's Multidimensional Organizational Commitment Questionnaire based on the responses of 316 nursing faculty.

\section{Results}

Affective commitment was the highest for both groups and full-time faculty show higher levels of commitment for each of the three types than part-time faculty.

The trend is especially apparent for normative commitment, where the mean difference was 0.93 and the effect statistic is the greatest (see table 1). While there is a significant difference in affective commitment between groups, the magnitude of the difference is medium to small when effect size considered $(\mathrm{d}=0.19)$ (Cohen, 1988).

For continuance commitment, the difference between full-time and part-time employment status approaches significance $(p<.05)$, however, the magnitude of the difference is small when effect size ( $d=.08)$ considered, (Cohen, 1988). For normative commitment, there is a significant difference between full-time and part-time employment status $(p<.001)$.

Table 1. Mean Differences and Effect Sizes of Employment Status for North Carolina Community College Faculty by Type of Commitment 


\begin{tabular}{|c|c|c|c|c|c|}
\hline Full-Time & Faculty(a) & $\begin{array}{l}\text { Part-Time } \\
\text { Faculty(b) }\end{array}$ & $\begin{array}{r}\text { Dif } \\
(a-b\end{array}$ & $\begin{array}{r}\text { ence } \\
p\end{array}$ & $\begin{array}{l}\text { Effect size } \\
\text { d }\end{array}$ \\
\hline $\begin{array}{l}\text { Affective } \\
\text { Commitment }\end{array}$ & 5.24 & 4.64 & 0.60 & $0.000 *$ & 0.19 \\
\hline $\begin{array}{l}\text { Continuance } \\
\text { Commitment }\end{array}$ & 4.52 & 4.28 & 0.24 & 0.091 & 0.08 \\
\hline $\begin{array}{l}\text { Normative } \\
\text { Commitment }\end{array}$ & 4.00 & 3.07 & 0.93 & $0.000 *$ & 0.29 \\
\hline
\end{tabular}

Note: $p=$ significance; $\mathrm{d}=$ effect-size (Cohen's d). ${ }^{*} \mathrm{p}<0.05$

Moreover, the magnitude of the difference is medium when effect size $(\mathrm{d}=0.29)$ considered, (Cohen, 1988). This data supports the conclusion that full-time community college faculty in North Carolina has significantly higher levels of affective and normative commitment when compared to their part-time counterparts, but there are no difference sin continuance commitment.

\section{Conclusions}

Affective Commitment. The research literature is non-existent for Meyer and Allen's conceptualization of organizational commitment modeled for full-time and part-time community college faculty. Therefore, a direct comparison of findings from the current study with findings from the literature is not possible. Meyer and Allen (1991) define affective commitment as "the employee's emotional attachment to, identification with, and involvement in the organization" (p. 67). This is generally seen as a favorable form of commitment, meaning that the individual stays with the organization because they want to stay. The results of this study produced a mean of for all the faculty (both full and part time) of $5.12(S D=1.53)$, just within the response anchor range for "slightly agree" (5.00 -5.99) on the seven point scale. This level of affective commitment is generally in accordance with other studies that have utilized the Affective Commitment Scale in the higher education setting. Messer (2006) reported a mean score of affective commitment for Tulsa Community College faculty at 5.23 (SD = 1.33). Carver (2008) reported that a national sample of nursing faculty produced a mean score of $4.41(S D=1.22)$ for affective commitment. his study's reported level of commitment, however, is slightly higher than the reported mean score of affective commitment for Christian higher education faculty at $3.11(\mathrm{SD}=1.12)$ on a 5point scale (Thomas 2008). Examination of affective commitment by faculty status shows that full-time faculty reported a mean level of affective commitment of $5.24(S D=1.47)$. Yet, the part-time faculty reported a mean level of affective commitment of $4.64(S D=1.61)$. Statistical analysis showed the mean levels of affective commitment between full-time and part-time faculty were significantly different $(\mathrm{p}<.05)$, though the effect size was small $(\mathrm{d}=0.19)$.

There is no comparative research using Meyer and Allen's conceptualization of organizational commitment modeled for full-time and part-time community college faculty. Therefore, a direct comparison of findings from the current study with findings from the literature is not possible. Yet, when comparisons are made with the few extant studies of organizational commitment among higher education faculty, the results of the current study do not match them. Speier-Bowman (1995), incorporating Mottaz's conceptualization of organizational commitment, showed that overall commitment levels were not different between full-time and part-time faculty at Denver area community colleges. Borchers \& Teahen (2001), using Mowday's (1979) instrument for organizational commitment, reported no difference in commitment levels between full-time and part-time faculty at two Mid-Western universities. Murphy (2009), using years of 
institutional service as a single-item proxy for institutional commitment, reported full-time tenured/tenure track faculty have more years of service than part-time (contingent) faculty. This difference was explained as a by-product of the tenure structure and process itself. However, Murphy (2009) further indicated that part-time faculty were generally as committed as their tenured/tenure-track counterparts since both groups had an average of seven years of service.

The current study indicates that full-time faculty may be more affectively committed than their part-time counterparts. One possible reason for this could be due to the fact that part-time faculty may have not been in the organization long enough to develop affective attachment. Lower levels of attachment may be a result of poor socialization to the college as opposed to actual time in employment.

It is common for part-time faculty to teach sections of classes that are scheduled in the evening, after most full-time faculty have finished their work day. As a result, part-time faculty may not feel integrated and included in the cultural fabric of the college. Effective socialization is also related to organizational support. It teaches the part-time faculty member the skills of his/her job as well as the norms and values or culture that guide faculty behavior at the particular institution in order to enhance employee performance (Anakwe \& Greenhaus, 1999). When the socialization process is institutionalized and made effective, some researchers believe it increases organizational commitment (Wanous, 1992).

Normative Commitment. The level of normative commitment is in accordance with Carver's (2008) study of nursing faculty that produced a mean score of $3.78(\mathrm{SD}=1.17)$ for normative commitment; but it is lower than Thomas' (2008) reported a mean score of normative commitment for Christian higher education faculty at $2.96(\mathrm{SD}=1.05)$ on a 5-point scale. When normative commitment was examined by faculty status, full-time faculty reported a mean level of normative commitment of $4.00(S D=1.53)$. In contrast, the part- time faculty reported a mean level of normative commitment of $3.07(S D=1.51)$. Results indicated that the mean levels of normative commitment between full-time and part-time faculty were significantly different ( $\mathrm{p}<$ $.05)$, though the effect size was medium $(\mathrm{d}=0.29)$.

A direct comparison of findings from the current study with findings from the literature is not possible. On the other hand, when comparisons are made with the few extant studies of organizational commitment among higher education faculty, the results of the current study do not match them. Several studies have reported no difference in commitment levels between fulltime and part-time faculty (Borchers \& Teahen, 2001; Murphy, 2009; Speier-Bowman,1995). Normative commitment is a measure of moral obligation, or loyalty, to the organization. The mean score for normative commitment was significantly higher for full- time faculty than for part-time faculty.

This finding could indicate that full-time faculty are more loyal to the organization and that part-time employees have less guilty feelings about leaving an organization than their fulltime counterparts. Carver (2008) demonstrated that normative commitment may vary with generations of nursing faculty. Hartmann and Bambacas (2000) reported low levels of normative commitment in their Australian study of part-time, academic staff workers. They concluded that changing jobs is more acceptable than it has been in past years.

Community colleges should pay more attention to how departments mentor new faculty members and to avenues for faculty development. These areas reflect ways that institutions can integrate all faculty into the organization. Integration might increase the perception of a supportive work environment, thereby increasing affective commitment. 


\section{References}

Anakwe, U. P., \& Greenhaus, J. H. (Fall 1999). Effective socialization of employees: Socialization content perspective. Journal of Managerial Issues, 11(3), 315-329.

Becker, H. S. (1960). Notes on the concept of commitment. American Journal of Sociology, 66, 32-40.

Borchers, A. S., \& Teahen, J. A. (2001). Organizational commitment of part-time and full-time faculty. Proceedings of the Association for Information Systems.

Carver, L. L. (2008). Organizational commitment and generational differences in nursing faculty. Unpublished dissertation, University of Nevada, Las Vegas.

Cohen, A. M., \& Brawer, F. B. (2003). The American community college. San Francisco: Jossey-Bass Publishers.

Dunham, R. B., Grube, J. A., \& Castenada, M. B. (1994). Organizational commitment: Theutility of an integrative definition. Journal of Applied Psychology, 370-380.

Gormley, D. K. (2005). Organizational climate, role ambiguity, role conflict and nurse facultywork balance: Influence on organizational commitment and turnover intention. Unpublished dissertation, University of Cincinnati.

Hackett, D. R., Bycio, P., \& Hausdorf, P. (1994). Further assessment of Meyer and Allen's(1991) three-component model of organizational commitment. Journal of Applied Psychology, 79, 15-23.

Johnson, B. (2001). Toward a new classification of nonexperimental quantitative research. Educational Researcher, 30(2), 3-13.

Meyer, J. P., \& Allen, N. J. (1991). A three-component conceptualization of organizational commitment. Human Resource Management Review, 1, 61-89.

Meyer, J. P., \& Allen, N. J. (1997). Commitment in the workplace: Theory, research, andapplication. Thousand Oaks, CA: SAGE Publications, Inc.

Meyer, J. P., Becker, T. E., \& Vandenberghe, C. (2004). Employee commitment and motivation: A conceptual analysis and integrative model. Journal of Applied Psychology, 89(6), 991-1007.

Meyer, J. P., Stanley, D. J., Herscovitch, L., \& Topolnytsky, L. (2002). Affective, continuance, and normative commitment to the organization: A meta-analysis of antecedents, correlates, and consequences. Journal of Vocational Behavior, 61, 20-52.

Mowday, R. T., Porter, L. W., \& Steers, R. M. (1982). Employee-organization linkages: Thepsychology of commitment, absenteeism, and turnover. New York: Academic Press, Inc.

North Carolina Community College System. (2006). Data trends and briefings. Retrieved September 18, 2007, from: http://www.ncccs.cc.nc.us/Reports/docs/data trends and briefings/Data_Trends June_29.pdf

North Carolina Community College System. (2007). A matter of facts: The North Carolinacommunity college system fact book. Retrieved September 18, 2007, from http://www.ncccs.cc.nc.us/Publications/docs/Publications/fb2007.pdf

Pratt, L. R. (1997). Disposable faculty: Part-time exploitation as management strategy. In C.Nelson (Ed.), Will teach for food: Academic labor in crisis (pp. 264-277). Minneapolis, MN: University of Minnesota Press.

Provasnik, S., \& Planty, M. (2008). Community colleges: Special supplement to the condition of education 2008 (NCES 2008-033).

Rifkin, T. (2000). Differences between the professional attitudes of full-time and part-time faculty. Paper presented at the American Association of Community Colleges Convention, Miami, FL. (ERIC Document Reproduction Service No. ED417783)

Thomas, J. C. (2008). Administrative, faculty, and staff perceptions of organizational climate and commitment in Christian higher education. Christian Higher Education, 7(3), 226-252.

Wallin, D. (2004). Valuing professional colleagues: Adjunct faculty in community and technical colleges. Community College Journal of Research and Practice, 28, 373-391.

Wallin, D. (Ed.). (2005). Adjunct faculty in community colleges: An academic administrator's guide to recruiting, supporting, and retaining great teachers. Bolton, MA: Anker Publishers.

Wanous, J. P. (1992). Organizational entry: Recruitment, selection, and socialization of newcomers. Reading, MA: Addison-Wesley.

Yoshioka, R. B. (Winter 2007). Part-time faculty in California: Successes, challenges, and future issues. New Directions for Community Colleges, 2007(140), 41-47. 